\title{
Intermittent Aeration in a Hybrid Moving Bed Biofilm Reactor for Carbon and Nutrient Biological Removal
}

\author{
Gaetano Di Bella ${ }^{1}\left[1\right.$ and Giorgio Mannina ${ }^{2,3,4, *}$ \\ 1 Faculty of Engineering and Architecture, University of Enna "kore", Cittadella Universitaria, 94100 Enna, \\ Italy; gaetano.dibella@unikore.it \\ 2 Department of Engineering, University of Palermo, Viale delle Scienze ed.8, 90128 Palermo, Italy \\ 3 College of Environmental Science and Engineering, Tongji University, 1239 Siping Road, Yangpu District, \\ Shanghai 200092, China \\ 4 School of Environmental and Municipal Engineering, Tianjin Chengjian University, 26 Jinjing Road, \\ Xiqing District, Tianjin 300384, China \\ * Correspondence: giorgio.mannina@unipa.it; Tel.: +39-09123896556
}

Received: 31 December 2019; Accepted: 9 February 2020; Published: 12 February 2020

\begin{abstract}
The paper presents an experimental study on a lab scale hybrid moving bed biofilm reactor with intermittent aeration. Specifically, a comparison between two different operating conditions was analyzed: continuous and intermittent aeration. Both continuous and intermittent aeration were monitored and compared in order to get the best operational conditions. The intermittent aeration campaign was sub-divided in three phases with different duration of alternation of aerobic and anoxic times and organic and nitrogen loading rates. The efficiency of $\mathrm{N}$-removal improved by $70 \%$ during the intermittent aeration. The best condition was observed with $40 \mathrm{~min}$ of aeration and 20 min of no-aeration, an organic loading rate of $2.2 \mathrm{kgCODm}^{-3} \mathrm{day}^{-1}$ and a nitrogen loading rate of $0.25 \mathrm{kgNm}^{-3} \mathrm{day}^{-1}$ : under these operational conditions the removal efficiencies for carbon and nitrogen were $93 \%$ and $90 \%$, respectively. The derived results provide the basis for WWTP upgrade in order to meet stricter effluent limits at low energy requirements.
\end{abstract}

Keywords: advanced wastewater treatment; intermittent aeration; SND; kinetic tests

\section{Introduction}

Conventional Activated Sludge (CAS) plants for wastewater treatment have several limitations related to high production of excess sludge, large surface area demand and low flexibility. In addition, their upgrading generally involves the use of multiple tanks (anoxic and aerobic) in order to obtain a complete nutrient removal. In the last few years there has been a growing attention regarding the receiving water body quality state [1]. In this context, several wastewater treatment plants need to be upgraded in order to meet stricter effluent limits. CAS upgrading requires additional space that may not be available near the existing treatment plants and, whenever the space is available, large capital investments are needed in crowded metropolitan areas [2]. For this reason, in recent years the recurrence to other innovative systems for wastewater treatment is increased [3].

A possible solution is the introduction of new strategies and/or advanced wastewater treatment technologies. Among the new strategies, the intermittent aeration can be an optimal solution. More specifically, the intermittent aeration is the reduction of the aeration time of the biological reactor by introducing periods without oxygen supply for the denitrification process [4]. In such a way, aerobic and anoxic phases are periodically alternated simply through the tuning of aeration system (i.e., fixed control of phase duration). In particular, the control strategy is addressed to complete nitrification in the aerobic phase, and to reduce nitrate concentration during the anoxic phase in order to maximize total nitrogen removal efficiency $[4,5]$. 
Although intermittent aeration can guarantee good quality effluent, there are some disadvantages: it is very difficult to manage correctly it on the existing process or to improve it since most processes target the oxidation ditch and need facilities related to selector, final clarifier and return of sludge and treated water [6]. In this context, the vital parameters for good operation in these processes are dissolved oxygen (DO) conditions depending on aeration/anoxic mixing, control of DO and mixed liquor suspended solid (MLSS) concentrations. In fact, despite the anoxic and aerobic conditions can be regulated alternatively for biological nitrogen removal, the diffusion of oxygen inside of biomass flocs can be optimized [7]. Regarding the adoption of new advanced wastewater treatment technologies for plant upgrading, hybrid moving bed biofilm reactor (HMBBR) can be of great interest [8,9]. HMBBR can be adopted to upgrade existing overloaded activated sludge plants without building new tanks. Regarding the traditional biological suspended biomass systems, HMBBRs are characterized by the jointly of both suspended and attached biomass. The latter grows attached on small carrier elements that move freely along with the water in the reactor [10]. The developed biofilm increases the total biomass, as well as the pollutant removal rate. In addition, the hybrid reactor improves the removal of various types of substances since different species of bacteria, particularly the slow growers (such as nitrifiers), are able to grow in the biofilm. Interesting advantages of HMBBRs, especially looking at the traditional fixed bed biofilm reactor (biofilters), regard the low head losses, no filter channeling and no need of periodic backwashing [11].

In order to better enhance carbon and nitrogen removal the combination of intermittent aeration strategy and HMBBR can be a very attractive solution. In fact, the implementation of a simultaneous-nitrification-denitrification (SND) process, directly in the bioreactor, seems to be the best choice for biological nutrient removal (in terms of space required) [12]. Several researchers with intermittent aeration strategy have been investigated [13-15]. However, there are only few studies dealing with intermittent aeration in moving bed biofilm reactor (MBBR) plants, especially for hybrid configuration, which, as far as authors are aware, are virtually absent [16].

Bearing in mind such considerations, the aim of the present study was to analyze the on/off aeration cycle in a HMBBR pilot plant, in order to verify the advantages and the limitation of this systems referring to carbon and nitrogen removal.

\section{Materials and Methods}

\subsection{The Pilot Plant}

The study was conducted in a HMBBR laboratory scale plant, installed at the Laboratory of Sanitary and Environmental Engineering of Enna University (Kore). In Figure 1 the layout of pilot plant is shown.

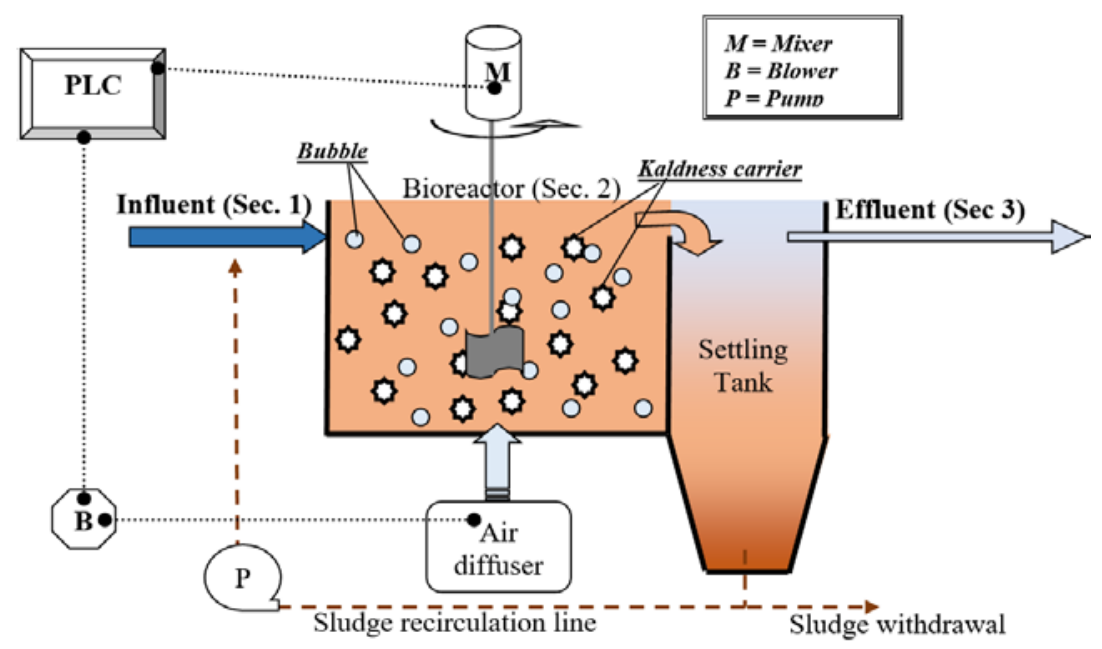

Figure 1. Schematic overview of the "intermittent aeration" (IA)-MBBR pilot plant and carrier features. 
The pilot plant was fed with synthetic wastewater with an influent flow of $1 \mathrm{~L} \cdot \mathrm{h}^{-1}$. The main compounds of the systemic mixture were sodium acetate, $\mathrm{NH}_{4} \mathrm{Cl}$ and $\mathrm{KPO}_{4}$. In particular, in order to control the influent concentration in different experimental periods, the dosage was changed.

The bioreactor was inoculated with activated sludge collected by the full-scale wastewater treatment plant of Enna (Italy). In order to optimize the process (mainly in terms of hydraulic performance) several operational condition changes have been carried out during the initial phase of the experimentation.

The biological phase was operated inside a bench-scale reactor designed to allow the development of suspended activated sludge and biofilm on free floating plastic carriers followed by a settlement unit. The setup consisted of a feeding tank $(100 \mathrm{~L})$, a bioreactor $(7.5 \mathrm{~L})$, where intermittent aeration occurs (equipped with air diffusers and mixer), and a settling tank (3.5 L). The biological reactor was filled with the Kaldnes ${ }^{\mathrm{TM}} \mathrm{K} 1$ carriers with a $33 \%$ filling ratio, corresponding to a specific surface area in the reactor of $150 \mathrm{~m}^{2} \cdot \mathrm{m}^{-3}$. The typical characteristic of Kaldnes ${ }^{\mathrm{TM}} \mathrm{K} 1$ carriers are: diameter $=9.1 \mathrm{~mm}$, height $=7.2 \mathrm{~mm}$, density $=0.95 \mathrm{~kg} \cdot \mathrm{L}^{-1}$ and porosity $=0.05$. The "effective biofilm growth surface" and "carrier density" in the reactor are $95 \mathrm{~m}^{2} \cdot \mathrm{m}^{-3}$ and $300 \mathrm{~m}^{2} \cdot \mathrm{m}^{-3}$ respectively [9].

In order to control the influent flow and sludge recirculation (from settling tank to bioreactor) the plant was equipped with 2 peristaltic pumps. For the start-up phase, $10 \mathrm{~L}$ of activated sludge, drawn from the aeration tank of the wastewater treatment plant of Enna (IT), was inoculated directly into the bioreactor.

Overall, the experimental campaign lasted 200 days: after cultivation in batch mode (about 30 days), the operational conditions were changed with the aim to compare the results of different strategies in "continuous aeration" (CA) and "intermittent aeration" (IA) mode. A Programmable Logic Controller (PLC) regulated the on/off aeration cycles.

More specifically, the experimental campaign was divided in four phases, each constituted by different "Time of aeration" (or so called "Aeration Time", $t_{a}$ ).

The first phase, called "Phase I", lasted 50 days in CA condition.

The subsequent phases lasted 50 days and were characterized by intermittent aeration.

The second phase, called "Phase II", was characterized by a total duration of the cycle $\left(t_{c}\right)$ of $30 \mathrm{~min}$, which $50 \%$ of it was in the aerated condition (both aeration time and anoxic time of $15 \mathrm{~min}$ each).

In the third and fourth phase (called "Phase III" and "Phase IV", respectively), the $t_{c}$ was increased until $60 \mathrm{~min}$ and was varied the duration of the aeration time: in Phase III, the $t_{\mathrm{a}}$ was 30 min with a $t_{a} / t_{c}$ ratio equal to 0.5 (similarly to Phase II), in Phase IV, the $t_{a}$ was increased to $40 \mathrm{~min}$, with a ratio $\mathrm{t}_{\mathrm{a}} / \mathrm{t}_{\mathrm{c}}=0.66$ (aeration time equal to $40 \mathrm{~min}$ and anoxic time of $20 \mathrm{~min}$ ).

On the other hand, with the aim to evaluate also the influence of the influent organic matter, the OLR (organic loading rate) was gradually increased during the 200 days of experimentation, defining different "periods" in terms of OLR conditions. More specifically, the first two phases (Phase I and II) were constituted each by a period (which lasted 50 days, coinciding with the duration of the phase). These periods were called "Period 0 " and "Period 1", respectively, and were characterized by an average value of OLR of $1.4 \mathrm{kgCOD} \mathrm{m}^{-3}$ day $^{-1}$.

The last phases were characterized each by two periods. More specifically, both Phase III and IV were constituted by two periods lasted 25 days where the influence of gradual increase of OLR was analyzed:

- In the Phase III, the periods called "Period 2A" and "Period 2B" were characterized by an OLR of 1.4 and $2.2 \mathrm{kgCOD} \mathrm{m}^{-3}$ day $^{-1}$, respectively;

- In the Phase IV, the periods called "Period 3A" and "Period 3B" were characterized by an OLR of 2.2 and $3.6 \mathrm{kgCOD} \mathrm{m}^{-3} \mathrm{day}^{-1}$, respectively.

All previous "Phases" (referred to different intermittent aeration strategies) and "Periods" (referred to different OLR) enabled us to investigate the kinetics aspects and the performance of phenomena of organic matter removal, nitrification and denitrification with a different strategy of aeration (continuous or intermittent), evaluating the best condition in terms of $t_{a} / t_{c}$ ratio and OLR. 
Furthermore, it should be specified that the variation of the NLR (nitrogen loading rate) was carried out gradually with a step-wise strategy and keeping the $\mathrm{C} / \mathrm{N}$ ratio (always equal to 14): the strategy was to study the carbon and nitrogen removal phenomena during "in series" operation and without stressing the biomass previously selected (especially the biofilm). On the other hand, for all operational conditions, the concentration of influent phosphorus (as orthophosphate) was ensured, with a $\mathrm{PO}_{4}-\mathrm{P}$ concentration always greater than $1 \%$ of the OLR.

Finally, the pilot plant operated under the condition of $11 \mathrm{~h}$ of HRT and 15 days of SRT.

In Table 1, the main operational conditions are summarized.

Table 1. Operational condition.

\begin{tabular}{|c|c|c|c|c|c|c|c|c|}
\hline Phase & Period & Duration & $\begin{array}{l}\text { Aeration } \\
\text { Condition }\end{array}$ & $\begin{array}{c}\text { Average } \\
\text { OLR }\end{array}$ & $\begin{array}{l}\text { Average } \\
\text { NLR }\end{array}$ & $\begin{array}{l}\text { Aeration } \\
\text { Time }\left(t_{a}\right)\end{array}$ & $\begin{array}{c}\text { Anoxic } \\
\text { Time }\left(t_{\text {na }}\right)\end{array}$ & $\begin{array}{c}\text { Cycle Time } \\
\left(t_{c}\right)\end{array}$ \\
\hline & & (day) & & $\begin{array}{c}\mathrm{kg}_{\text {COD }} \mathrm{m}^{-3} \\
\text { day }^{-1}\end{array}$ & $\begin{array}{c}\mathrm{kg}_{\mathrm{N}} \mathrm{m}^{-3} \\
\text { day }^{-1}\end{array}$ & $(\min )$ & $(\min )$ & $(\min )$ \\
\hline I & $\begin{array}{c}\mathbf{0} \\
\text { (Day 1-50) }\end{array}$ & 50 & continuous & $1.4 \pm 0.1$ & $0.1 \pm 0.01$ & continuous & - & - \\
\hline II & $\begin{array}{c}\mathbf{1} \\
\text { (Day 51-100) }\end{array}$ & 50 & intermittent & $1.4 \pm 0.1$ & $0.1 \pm 0.01$ & 15 & 15 & 30 \\
\hline \multirow[t]{2}{*}{ III } & $\begin{array}{c}\mathbf{2 A} \\
\text { (Day } \\
101-125)\end{array}$ & 25 & intermittent & $1.4 \pm 0.1$ & $0.1 \pm 0.01$ & 30 & 30 & 60 \\
\hline & $\begin{array}{c}\text { 2B } \\
\text { (Day } \\
126-150)\end{array}$ & 25 & intermittent & $2.2 \pm 0.1$ & $0.15 \pm 0.01$ & 30 & 30 & 60 \\
\hline \multirow[t]{2}{*}{ IV } & $\begin{array}{c}\text { 3A } \\
\text { (Day } \\
151-175)\end{array}$ & 25 & intermittent & $2.2 \pm 0.1$ & $0.15 \pm 0.01$ & 40 & 20 & 60 \\
\hline & $\begin{array}{c}\text { 3B } \\
\text { (Day } \\
175-200)\end{array}$ & 25 & intermittent & $3.3 \pm 0.1$ & $0.24 \pm 0.01$ & 40 & 20 & 60 \\
\hline
\end{tabular}

\subsection{Analytical Methods}

During plant management, the influent wastewater (section "Sec.1" of Figure 1), the mixed liquor in the biological reactor (section "Sec.2" of Figure 1) and the effluent flow (section "Sec.3" of Figure 1), were sampled meanly two times per week and samples were analyzed evaluating total and volatile suspended solids (TSS and VSS), soluble COD, $\mathrm{NH}_{4}-\mathrm{N}, \mathrm{NO}_{2}-\mathrm{N}$ and $\mathrm{NO}_{3}-\mathrm{N}$ [17]. Further, the dissolved oxygen (DO), $\mathrm{pH}$ and temperature ( $\mathrm{T}$ ) were daily measured using a handheld Multi 340i meter (WTW). It is worth noting that the analyses of the suspended biomass in the mixed liquor section were carried out on the aerated sludge. More specifically, the analysis of total suspended solids (SS) and volatile (VSS) was carried out by filtering the sample with a 1.2-micron filter (GF/C). Once dried at $105^{\circ}$, the residual content on the filter was evaluated and, after having compared it to the volume of filtered sample, they were determined in mgSS/L. Similarly, the VSS were evaluated on the volatilized solid content, after incineration at $550^{\circ} \mathrm{C}$. On the other hand, biomass attached to carriers was measured by weighing $10-20$ dried $\left(105^{\circ} \mathrm{C}, 1 \mathrm{~h}\right)$ carries from the reactors and 10-20 unused carriers. The biofilm concentration was evaluated as the difference between unused and used carriers multiplied by the number of carriers in one liter [18].

Finally, in order to analyze the physiological conditions of the biomass and the kinetic behavior, the activated sludge functional microorganism groups (nitrifiers and heterotroph denitrifies) were characterized through determinations of maximum specific ammonia utilization rate (AUR) and nitrate utilization rate (NUR) test [19].

More specifically, to determine nitrification activity in the IA process, batch nitrification tests were conducted with the culture from the IA tanks (after the 60th day). A 3-L glass bottle was used as the batch reactor. Two and half liters of mixed liquor from an IA tank were introduced into the batch reactor for each batch nitrification test. Ammonium chloride $\left(\mathrm{NH}_{4} \mathrm{Cl}\right)$ was added into the batch reactor. The ratio of the influent $\mathrm{C} / \mathrm{N}$ at the beginning of each batch test was maintained the same as that in the 
influent to the continuous flow IA tanks, by adding methanol to the batch reactor. The batch reactor was well mixed with a magnetic stirrer, and continuously aerated through a diffusing stone with an airflow rate of $500 \mathrm{~mL} \cdot \mathrm{min}^{-1}$. Six samples $(10 \mathrm{~mL}$ each) were drawn at designated intervals of $15 \mathrm{~min}$ and analyzed for $\mathrm{NH}_{4}-\mathrm{N}, \mathrm{NO}_{3}-\mathrm{N}, \mathrm{NO}_{2}-\mathrm{N}$ and VSS.

On the other hand, denitrification activity of the culture in the IA tank was also studied in batch tests. In these batch tests, the IA tank was operated as a batch reactor without aeration. At the beginning of the batch tests, the batch reactor was spiked with potassium nitrate $\left(\mathrm{KNO}_{3}\right)$ to result in different initial concentrations of nitrate-nitrogen (ranged from 30 to $40 \mathrm{mg} \cdot \mathrm{L}^{-1}$ ) in the batch tests. Each batch test was conducted after steady state of the IA process was achieved in the tank. The initial $\mathrm{C} / \mathrm{N}$ ratio in the batch tests was maintained at the same value of influent in bench scale, by adding AcNa to the batch reactor. The batch reactor was then sealed and completely mixed with a magnetic stirrer. Mixed liquor samples $(10 \mathrm{~mL})$ were taken from the batch reactor at designated intervals of 15 min for analyses of $\mathrm{NO}_{3}-\mathrm{N}, \mathrm{NO}_{2}-\mathrm{N}$ and VSS to monitor the denitrification activity.

\section{Results and Discussion}

In the following paragraphs the performance of the pilot plant in all the experimental periods have been discussed. In Table 2, the values relating to the quality of the influent and effluent were previously shown (with the average removal efficiency in the period coupled).

Table 2. Influent and effluent qualities.

\begin{tabular}{|c|c|c|c|c|}
\hline Period & Parameter & Influent & Effluent & Removal \\
\hline & & $\begin{array}{c}\text { Average } \\
\text { Concentration } \\
(\mathrm{mg} / \mathrm{L})\end{array}$ & $\begin{array}{c}\text { Average } \\
\text { Concentration } \\
(\mathrm{mg} / \mathrm{L})\end{array}$ & Average (\%) \\
\hline \multirow{3}{*}{0} & COD & $380 \pm 26$ & $47 \pm 12$ & $87 \pm 4$ \\
\hline & $\mathrm{NH}_{4}$ & $30 \pm 4.5$ & $14 \pm 4.5$ & $67 \pm 11$ \\
\hline & $\mathrm{P}_{\text {TOT }}$ & $5.5 \pm 0.3$ & $4.2 \pm 0.1$ & $14.3 \pm 2$ \\
\hline \multirow{3}{*}{1} & COD & $380 \pm 35$ & $13 \pm 5$ & $96 \pm 2$ \\
\hline & $\mathrm{NH}_{4}$ & $30 \pm 1.5$ & $3.5 \pm 1.7$ & $87 \pm 3$ \\
\hline & $\mathrm{P}_{\mathrm{TOT}}$ & $5.5 \pm 0.8$ & $1.6 \pm 0.25$ & $65 \pm 5$ \\
\hline \multirow{3}{*}{$2 \mathrm{~A}$} & COD & $380 \pm 54$ & $13 \pm 4$ & $97 \pm 1$ \\
\hline & $\mathrm{NH}_{4}$ & $30 \pm 2.5$ & $1.7 \pm 1.6$ & $80 \pm 10$ \\
\hline & $\mathrm{P}_{\mathrm{TOT}}$ & $5.5 \pm 0.7$ & $2.6 \pm 0.1$ & $47 \pm 2$ \\
\hline \multirow{3}{*}{$2 B$} & COD & $640 \pm 31$ & $24 \pm 18$ & $95 \pm 3$ \\
\hline & $\mathrm{NH}_{4}$ & $45 \pm 0.5$ & $0.6 \pm 0.2$ & $83 \pm 5$ \\
\hline & $\mathrm{P}_{\mathrm{TOT}}$ & $8.5 \pm 0.3$ & $1.6 \pm 0.5$ & $71 \pm 6$ \\
\hline \multirow{3}{*}{$3 \mathrm{~A}$} & COD & $640 \pm 11$ & $24 \pm 3$ & $96 \pm 2$ \\
\hline & $\mathrm{NH}_{4}$ & $45 \pm 3.9$ & $1.4 \pm 0.6$ & $89 \pm 1$ \\
\hline & $\mathrm{P}_{\text {TOT }}$ & $8.5 \pm 0.1$ & $5.3 \pm 0.1$ & $26 \pm 2$ \\
\hline \multirow{3}{*}{$3 B$} & COD & $1050 \pm 70$ & $55 \pm 13$ & $94 \pm 2$ \\
\hline & $\mathrm{NH}_{4}$ & $61 \pm 5$ & $0.35 \pm 0.15$ & $93 \pm 2$ \\
\hline & $\mathrm{P}_{\mathrm{TOT}}$ & $12 \pm 0.5$ & $6.3 \pm 0.5$ & $38 \pm 3$ \\
\hline
\end{tabular}

\subsection{COD Removal and Biomass Growth}

In Figure 2, the results of organic removal performance and biomass growth, in terms of COD concentration and the MLSS variation trend in the bioreactor, are shown.

High carbon performances were achieved in both aeration plant strategies (i.e., continuous and intermittent). More specifically, under all operating conditions, organics were removed satisfactory.

The organic removal performance increased slowly with the growth of attached biomass: the average organic removal increased from $81 \%$ to $87 \%$ during the continuous aeration period (Phase I), 
and $93 \%-95 \%$ in the subsequent periods with intermittent aeration, despite the increase in OLR in the Periods $2 \mathrm{~B}$ and $3 \mathrm{~B}$.
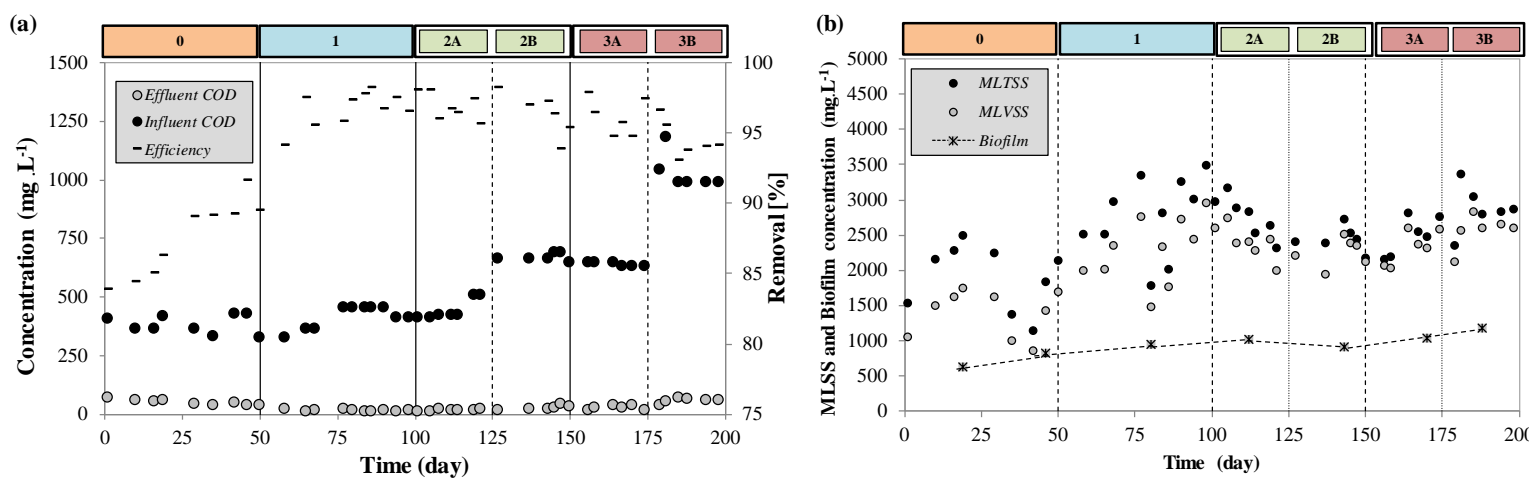

Figure 2. COD concentration in the influent and effluent flow (a) and mixed liquor suspended solid (MLSS) variation in the bioreactor (b).

Once the biofilm was growing, the invariance of the data of organic removal performance confirms the results reported by other authors concerning the intermittent aeration strategy applied to other installations $[20,21]$. Therefore, the HMBBR under intermittent aeration showed that the growth of heterotrophic biomass as biofilm is a further advantage in terms of COD removal and biological process stability.

In this context, it is important to underline that the growth of the biofilm on the physical supports occurred mainly during the Phase I, with a "continuous aeration". More specifically, the concentration of the biofilm reached at the end of the Period 0 (namely, around $1 \mathrm{~g} \cdot \mathrm{L}^{-1}$ ) was maintained almost constant during the sub-sequential intermittent aeration phases. In fact, the biological stress operated by alternating the aerated and non-aerated stages can limit the biofilm growth. To confirm such a fact, during the Phase IV (in both Period 3A and 3B), when the length of aeration period was increased, it seems that the biofilm growth starts again.

On the other hand, during all periods of the "intermittent aeration", in Phases II-IV, both the suspended biomass and biofilm concentration amounted to the almost constant values reached at the end of Period 0, with a constant SRT equal to 15 days. More specifically, the MLSS concentration was maintained at about 2.5-3 g. $\mathrm{L}^{-1}$ during the Period 1 and $2 \mathrm{~A}$, and slightly less than $2.5 \mathrm{~g} \cdot \mathrm{L}^{-1}$ in subsequent Periods $2 \mathrm{~A}-2 \mathrm{~B}$ and $3 \mathrm{~g} \cdot \mathrm{L}^{-1}$ in the Periods $3 \mathrm{~A}-3 \mathrm{~B}$. By contrast, the relationship between the VSS and TSS grew during the experimental campaign, from $70 \%$ to $85 \%$ : probably, this phenomenon was due to mixed liquor seeding by the biofilm dethatched. A further increase $(3 \%-5 \%)$ was observed when the organic loading rate was increased during the Periods $2 \mathrm{~B}$ and $3 \mathrm{~B}$.

\subsection{Nitrification and Denitrification Phenomena}

Regarding the nitrogen removal, Figure 3 reports the nitrogen data nitrified and denitrified.

As shown in Figure 3a, the nitrates were produced after the 10th day, confirming the growth of autotrophic biomass. More specifically, the nitrification process improved in time, according to data shown in Figure 3b,c, because the autotrophic organisms grew in both the suspended and attached form. In general, the optimum nitrification has been reached when the longest aeration phase was applied (Phase IV), confirming an average nitrification greater than $90 \%$.

Concerning the nitrogen removal, as expected, the denitrification processes occurred only when the intermittent aeration was performed. In general, a good nitrogen removal was reached in all IA phases. The total nitrogen removal was mainly due to the SND process in the reactor. In particular, when the aeration phase was turned off, the DO in the reactor decreased from about $2-3$ to $0 \mathrm{mg} \cdot \mathrm{L}^{-1}$ in a few minutes and a sufficient carbon source was available due to the supplemented influent, which was good for denitrification. In this context, it is interesting to underline that the nitrates totally 
disappeared in Period 3B, when the intermittent aeration was performed with 40 min of $t_{a}$ and 20 min of no-aeration $\left(t_{n a}\right)$ and, in particular, when OLR was equal to $3.6 \mathrm{kgCOD} \mathrm{m}^{-3} \mathrm{day}^{-1}$. In this case, the total nitrogen concentrations in the effluent were kept less than $1-2 \mathrm{mg} \cdot \mathrm{L}^{-1}$. On the contrary, during the period in continuous aeration, although the ammonia nitrogen was nitrified with an efficiency $>60 \%$, the removal of total nitrogen was negligible ( $<20 \%$ because there are not denitrification).

More detailed findings, confirming the general behavior described in the previous figures, can be deduced from Figure 3c. In particular, the analysis of the average performance of nitrification and denitrification in each period demonstrated other important results.

In Period 0 the denitrification processes did not occur, because the anoxic conditions were never established. By contrast, the nitrification was already satisfactory ( $>60 \%$ ) because the inoculation was carried out with activated sludge collected from a WWTP where the autotrophic bacteria were present, furthermore, the pilot plant was conducted with high SRT, in order to favor the biofilm growth on the carrier.

In Period 1, the nitrification performance further increased, because the "slow-growing biomass" continued to grow. The denitrification reached satisfactory values of removal $(70 \%)$ because the phases of "no-aeration" guarantee the anoxic conditions, which were absent in the period to continuous aeration.

In Phase III, similarly for both Period 2A and 2B, the performance of nitrification did not change, despite the duration of the aeration stage was doubled compared to the previous period (from 15 to $30 \mathrm{~min}$ ): this is probably due to the fact that the ta/tc ratio was maintained at a value of 0.5 . Probably in this context, the aerobic autotrophic bacteria have no particular benefit from the increase in continuous aeration period due to the identical duration of the period where the oxygen was absence. On the contrary, it seems that the longer "stopping" in the bioreactor aeration caused a slight decrease in the nitrification. As for the denitrification, in Period 2A the pilot plant shows a behavior similar to performance the "nitrification" in the transition from Period 0 to Period 1: the denitrification remains almost constant at $70 \%$ value, because the denitrified bacteria were not the favorite by the increase of the no-aerated phase, due to the not perfect balance in duration between aerated and non-aerated phases (similarly to what happened for autotrophic bacteria). On the other hand, in Period 2B the increase of substrate availability (mainly in terms of biodegradable carbon) improved the denitrification performance of heterotrophic bacteria, which are less limited by the organic substrate.

In Phase IV, the new cycle conditions improved the overall performance of both nitrogen transformation phenomena. The performance of nitrification greatly increased (from $83 \%$ to $86 \%$ in Period 3A and 91\% in Period 3B) despite the total cycle time was maintained at 60 min. More specifically, in Period 3A and 3B, in fact, the duration of the aeration phase was increased at the expense of that of "no-aeration" (the ta/tc ratio was now of 0.66 ): this has contributed to favor the kinetics of autotrophic bacteria, but did not alter substantially the kinetics of denitrifying bacteria (which have guaranteed almost constant performance). By contrast, the latter were helped by the increase in the carbonaceous substrate only during Period $3 \mathrm{~B}$, so the denitrification performances increased from $81 \%$ (Period 3A) to over 90\% (COD concentration increased from about 650 , in Period $3 \mathrm{~A}$, to about $1050 \mathrm{mg} / \mathrm{L}$, in Period 3B).

In order to complete nitrogen removal discussion, Figure $3 \mathrm{e}$ summarizes the mass balance of nitrogen forms. According with what described above, the graph clearly shows that:

- $\quad$ Nitrified nitrogen increased over time (from Period 0 to Period 3B), depending on the stabilization of the nitrifying bacteria and the optimization of the operating conditions;

- The nitrogen lost by cell synthesis was in the range 33\%-38\% approximately;

- In almost all experimental periods, the removal of total nitrogen was attributable to a maximum of $65 \%$ to the net nitrification of ammonia nitrogen and to $35 \%$ of cell assimilation. 

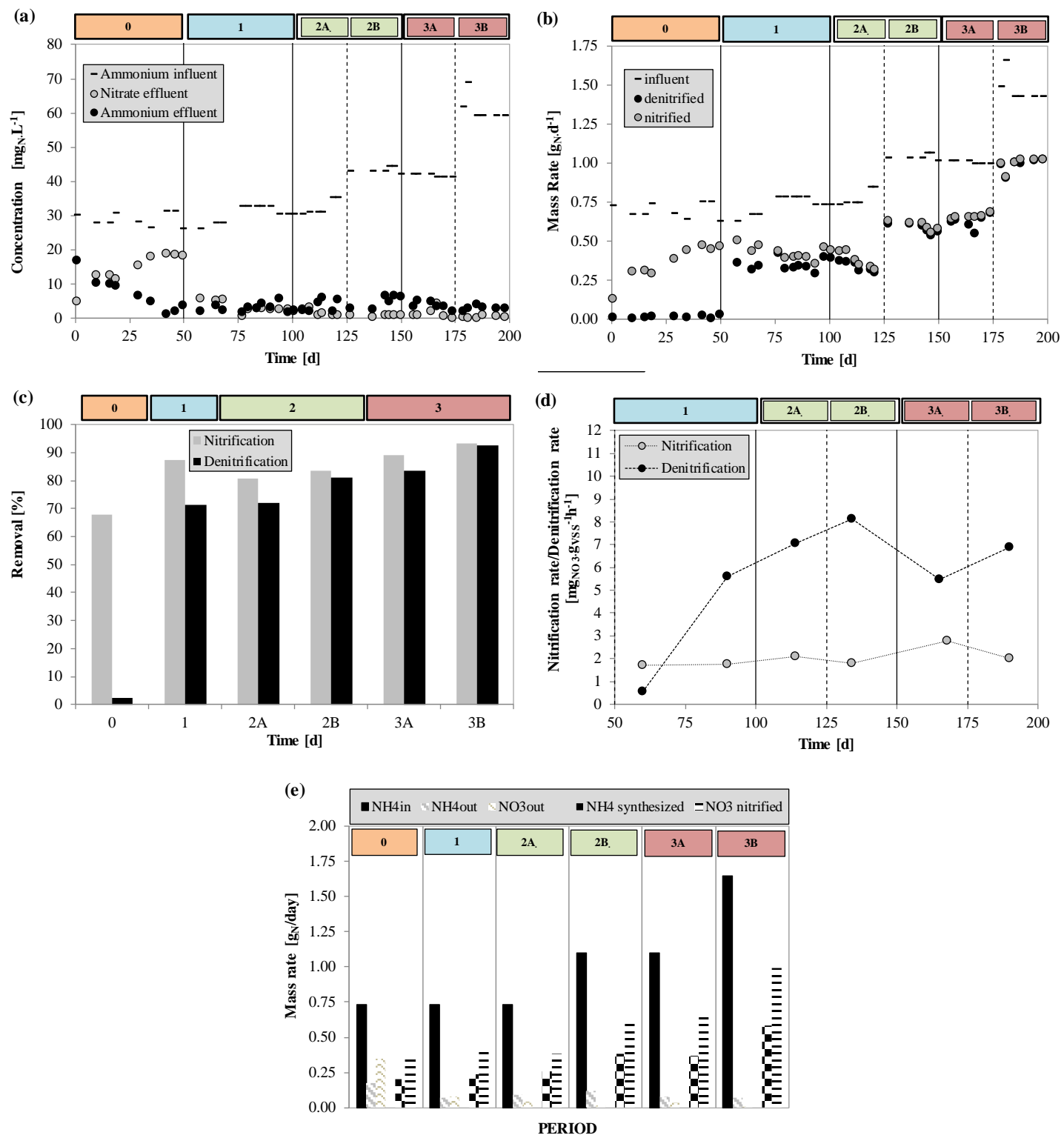

Figure 3. $\mathrm{NH}_{4}-\mathrm{N}$ and $\mathrm{NO}_{3}-\mathrm{N}$ concentration in the influent and effluent (a), nitrogen denitrified and nitrified (b), efficiency of removal (c), specific rate of nitrification/denitrification process (d) and nitrogen mass balance (e).

The results observed in terms of performance were confirmed by the specific removal of nitrate and ammonium, shown in the Figure $3 \mathrm{~d}$ (in terms of specific rate of nitrification and denitrification). The data reported in the graphs were calculated on the basis of the individual tests of AUR and NUR, reported in Figures 4 and 5. More specifically, the analysis of the AUR and NUR test confirmed that both nitrification and denitrification activities were satisfactory, with velocities of nitrification and denitrification respectively equal to:

- $\quad 1.7 \pm 0.5 \mathrm{mgNO}_{3}-\mathrm{N}_{\text {nitrified }} \cdot \mathrm{gSS}^{-1} \cdot \mathrm{h}^{-1}$ and $5.58 \pm 0.8 \mathrm{mgNO}_{3}-\mathrm{N}_{\text {denitrified }} \cdot \mathrm{gSS}^{-1} \cdot \mathrm{h}^{-1}$ in Period 1 (at the end of the period),

- $2.09 \pm 0.15 \mathrm{mgNO}_{3}-\mathrm{N}_{\text {nitrified }} \cdot \mathrm{gSS}^{-1} \cdot \mathrm{h}^{-1}$ and $7.05 \pm 1.4 \mathrm{mgNO}_{3}-\mathrm{N}_{\text {denitrified }} \cdot \mathrm{gSS}^{-1} \cdot \mathrm{h}^{-1}$ in Period $2 \mathrm{~A}$,

- $1.79 \pm 0.21 \mathrm{mgNO}_{3}-\mathrm{N}_{\text {nitrified }} \cdot \mathrm{gSS}^{-1} \cdot \mathrm{h}^{-1}$ and $8.11 \pm 1.4 \mathrm{mgNO}_{3}-\mathrm{N}_{\text {denitrified }} \cdot \mathrm{gSS}^{-1} \cdot \mathrm{h}^{-1}$ in Period $2 \mathrm{~B}$,

- $\quad 2.78 \pm 0.4 \mathrm{mgNO}_{3}-\mathrm{N}_{\text {nitrified }} \cdot \mathrm{gSS}^{-1} \cdot \mathrm{h}^{-1}$ and $5.48 \pm 0.2 \mathrm{mgNO}_{3}-\mathrm{N}_{\text {denitrified }} \cdot \mathrm{gSS}^{-1} \cdot \mathrm{h}^{-1}$ in Period $3 \mathrm{~A}$,

- $2.01 \pm 0.3 \mathrm{mgNO}_{3}-\mathrm{N}_{\text {nitrified }} \cdot \mathrm{gSS}^{-1} \cdot \mathrm{h}^{-1}$ and $6.88 \pm 0.4 \mathrm{mgNO}_{3}-\mathrm{N}_{\text {denitrified }} \cdot \mathrm{gSS}^{-1} \cdot \mathrm{h}^{-1}$ in Period 3B. 
It is important to underline that the specific nitrate formation rates were in the range of 1.7-2.8 $\mathrm{mgNO}_{3}-\mathrm{N} \mathrm{gSS}{ }^{-1} \mathrm{~h}^{-1}$, which were within the literature range (namely, $0.78-7 \mathrm{mgNO}_{3}-$ $\left.\mathrm{N}_{\text {nitrified }} \cdot g S S^{-1} \cdot \mathrm{h}^{-1}\right)$. [22]. Similar results were derived for the specific denitrification rates or specific ammonium oxidation rates $\left(2.76-9.05 \mathrm{mgNO} \mathrm{N}_{3}-\mathrm{N}_{\text {denitrified }} \cdot \mathrm{gSS}^{-1} \cdot \mathrm{h}^{-1}\right)$.

The overall AUR data reported in Figure $3 \mathrm{~d}$ also show that the nitrification activity remained meanly constant for all periods, with a small increase in Period 3A. Contrarily, the rate of denitrification only improved from Period 1 to Period 2B. In Period 3A the denitrification rate decreased slightly, due to the reduction of the no-aerated time. However, it is important to underline that the denitrification was generally improved when a greater OLR was applied for the specific period (2B and $3 \mathrm{~B})$.
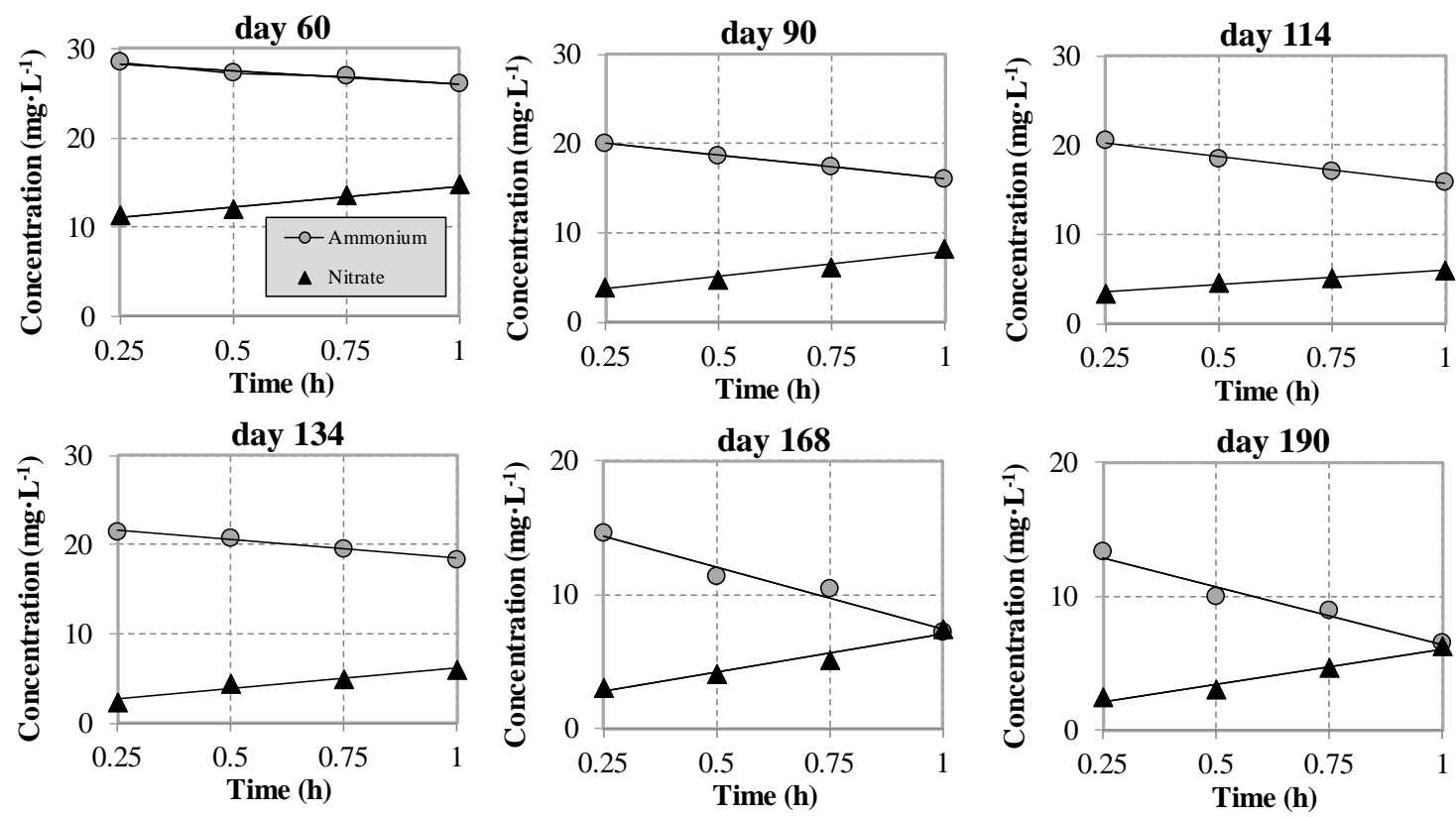

Figure 4. Ammonia utilization rate (AUR) test.
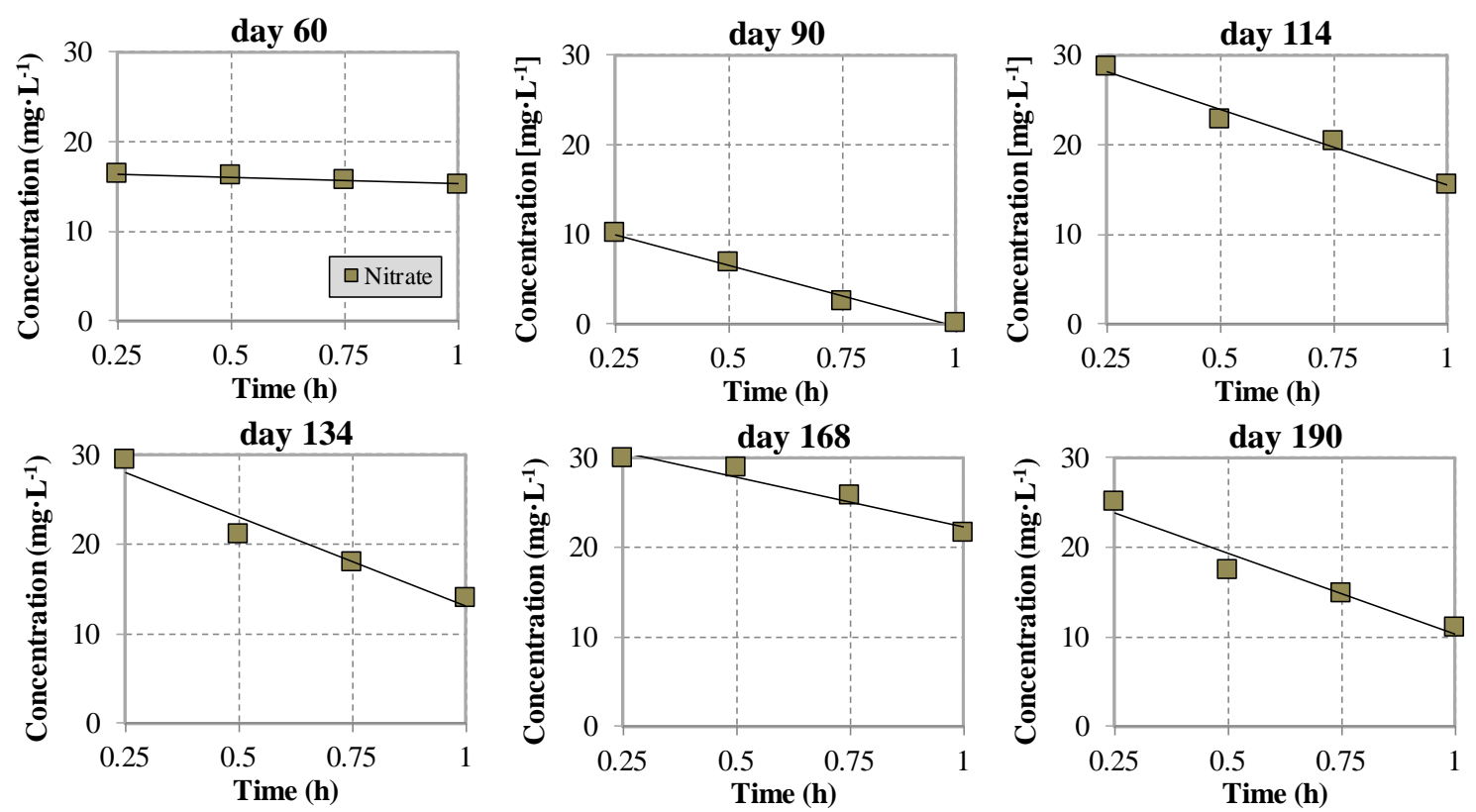

Figure 5. Nitrate utilization rate (NUR) test. 


\subsection{Phosphorus Removal}

In general, if an anaerobic phase was not planned, the removal of phosphorus is almost exclusively due to the metabolic needs of the biomass. Nevertheless, in the case of IA operation without automatic control, the analysis of phosphorus removal can emphasize the real conditions of anoxia and anaerobic conditions that occur during the process, especially when a biofilm is present in the bioreactor. In particular, if the removal of phosphorus exceeds $10 \%-15 \%$, it is possible to deduce that there is a concrete contribution of phosphorus accumulating organisms in phosphorus removal [23,24]. The phenomenon is due to the development of an anaerobic layer periodically formed in the biofilm during the no-aerated period.

In Figure 6 the phosphorus concentration and the performance of removal were shown.

(a)

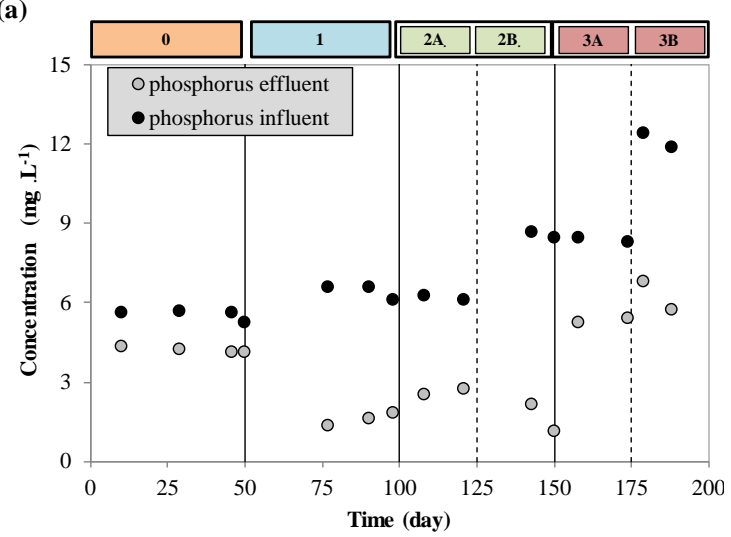

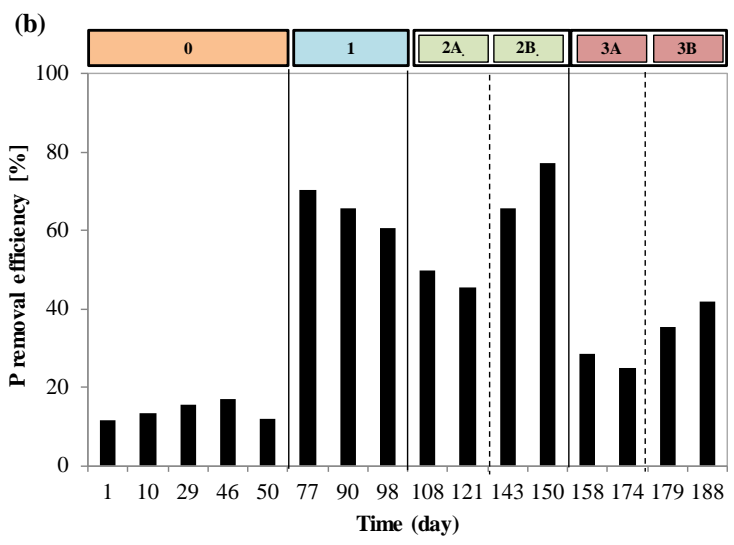

Figure 6. Total phosphorus concentration in the influent and effluent (a) and removal efficiency (b).

In general, the data reported in Figure 6 show that during the CA period the phosphorous removal is due only to the metabolic needs. On the other hand, during the IA period the phosphorous removal increased. Nevertheless, in this case, as shown by the data reported in Figure $6 \mathrm{~b}$, it is evident the performance difference between Periods 1-2A-2B and Period 3A-3B.

In Periods 1, 2A and 2B, the high performance of $P$ removal confirms that the anoxic denitrification of nitrates probably competes with the anaerobic metabolism of Poly-P (PHB storage and P release), which subsequently used the $\mathrm{P}$ released in the anaerobic phase. So, probably during the time of non-aerated phase both the anoxic and anaerobic phase occur. During Period $3 \mathrm{~A}$ and 3B this phenomenon is attenuated and the non-aerated time is largely used for the anaerobic denitrification, with reduction of the total performances of phosphorous removal by Poly-P.

Finally, the analysis of Figure $6 \mathrm{~b}$ also shows that the increase in the carbon load, in both Periods $2 \mathrm{~B}$ and $3 \mathrm{~B}$, favors the anaerobic metabolism operated by the phosphorus accumulating bacteria: this is due to an improvement in the polyhydroxybutyrate (PHB) storage as uncontrolled effect of the greater organic matter concentration during the competitive phase carried out by denitrifying bacteria and polyphosphate-accumulating organisms (PAOs) [25-28].

\section{Conclusions}

The HMBBR process was implemented with intermittent aeration to regulate the SND process. When treating a regular wastewater, the TN were approximately $90 \%$, and their concentrations in the unfiltered effluent were generally less than $5 \mathrm{mg} / \mathrm{L}$. In particular, after an integrated analysis of different operational condition, the best IA period was obtained by alternating 40-min of aeration with 20 min of non-aeration.

The combination of intermittent aeration and biofilm-suspended biomass in the reactor played a critical role in the success of the process to achieve enhanced nutrient removal and energy saving. 
Therefore, the derived results offer a very useful database for real WWTPs aimed at establishing a good compromise between strict effluent quality and energy consumption.

Author Contributions: G.D.B. conceived and designed the experiments concerning biological Treatment; G.M. conceived and designed the experiments concerning biological Treatment, supervised the work and co-wrote this paper. All authors have read and agree to the published version of the manuscript.

Funding: This research received no external funding.

Acknowledgments: The authors want to thank Maria Gabriella Giustra for their precious help with pilot plant operation.

Conflicts of Interest: The authors declare no conflict of interest.

\section{References}

1. Directive 91/271 of the European Union. EC. Council Directive 91/271/EEC of 21 May 1991 concerning urban waste water treatment. Off. J. 1991, L135, 40-52.

2. Wang, J.; Yang, N. Partial nitrification under limited dissolved oxygen conditions. Process Biochem. 2004, 39, 1223-1229.

3. Di Bella, G.; Torregrossa, M. Simultaneous nitrogen and organic carbon removal in aerobic granular sludge reactors operated with high dissolved oxygen concentration. Bioresour. Technol. 2013, 142, 706-713. [CrossRef] [PubMed]

4. Carucci, A.; De Mola, M.; Rolle, E.; Smurra, P. A model to control intermittent aeration phases. Water Sci. Technol. 2002, 46, 99-106. [CrossRef]

5. Hanhan, O.; Artan, N.; Orhon, D. Retrofitting activated sludge systems to intermittent aeration for nitrogen removal. Water Sci. Technol. 2002, 46, 75-82. [CrossRef]

6. Kim, B.K.; Chang, D.; Son, D.J.; Kim, D.W.; Choi, J.K.; Yeon, H.J.; Yoon, C.Y.; Fan, Y.; Lim, S.Y.; Hong, K.H. Wastewater Treatment in Moving-Bed Biofilm Reactor operated by Flow Reversal Intermittent Aeration System. World Acad. Sci. Eng. Technol. 2011, 60, 581-584.

7. Hidaka, T.; Yamada, H.; Kawamura, M.; Tsuno, H. Effect of dissolved oxygen conditions on nitrogen removal in continuously fed intermittent-aeration process with two tanks. Water Sci. Technol. 2002, 45, 181-188. [CrossRef]

8. Mannina, G.; Di Trapani, D.; Viviani, G.; Ødegaard, H. Modelling and dynamic simulation of hybrid moving bed biofilm reactors: Model concepts and application to a pilot plant. Biochem. Eng. J. 2011, 56, 23-36. [CrossRef]

9. Mannina, G.; Viviani, G. Hybrid moving bed biofilm reactors: An effective solution for upgrading a large wastewater treatment plant. Water Sci. Technol. 2009, 60, 1103-1116. [CrossRef]

10. Ødegaard, H.; Rusten, B.; Westrum, T. A new moving bed biofilm reactor-applications and results. Water Sci. Technol. 1994, 29, 157-165. [CrossRef]

11. Pastorelli, G.; Canziani, R.; Pedrazzi, L.; Rozzi, A. Phosphorus and nitrogen removal in Moving-Bed Sequencing Batch Biofilm Reactors. Water Sci. Technol. 1999, 40, 169-176. [CrossRef]

12. Sliekers, A.; Derwort, N.; Gomez, J.L.C.; Strous, M.; Kuenen, J.G.; Jetten, M.S.M. Completely Autotrophic Nitrogen Removal Over Nitrite in One Single Reactor. Water Res. 2002, 36, 2475-2482. [CrossRef]

13. Araki, H.; Koga, K.; Inomae, K.; Kusuda, T.; Awaya, Y. Intermittent aeration for nitrogen removal in small oxidation ditches. Water Sci. Technol. 1990, 22, 131-138. [CrossRef]

14. Capodici, M.; Di Bella, G.; Di Trapani, D.; Torregrossa, M. Pilot scale experiment with MBR operated in intermittent aeration condition: Analysis of biological performance. Bioresour. Technol. 2015, 177, 398-405. [CrossRef] [PubMed]

15. Campo, R.; Di Bella, G.; Capodici, M.; Torregrossa, M. The role of EPS in the foaming and fouling for a MBR operated in intermittent aeration conditions. Biochem. Eng. J. 2017, 118, 41-52. [CrossRef]

16. Luostarinen, S.; Luste, S.; Valentın, L.; Rintala, J. Nitrogen removal from on-site treated anaerobic effluents using intermittently aerated moving bed biofilm reactors at low temperatures. Water Res. 2006, 40, 1607-1615. [CrossRef]

17. APHA. Standard Methods for the Examination of Water and Wastewater, 20th ed.; American Public Health Association: Washington, DC, USA, 1998. 
18. Di Trapani, D.; Di Bella, G.; Mannina, G.; Torregrossa, M.; Viviani, G. Comparison between moving bed-membrane bioreactor (MB-MBR) and membrane bioreactor (MBR) systems: Influence of wastewater salinity variation. Bioresour. Technol. 2014, 162, 60-69. [CrossRef]

19. Kristensen, G.H.; Jørgensen, P.E.; Henze, M. Characterization of Functional Microorganism Groups and Substrate in Activated Sludge and Wastewater by AUR; NUR and OUR. Water Sci. Technol. 1992, 25, $43-57$. [CrossRef]

20. Wang, Y.; Yu, S.; Shi, W.; Bao, R.; Zhao, Q.; Zuo, X. Comparative performance between intermittently cyclic activated sludge-membrane bioreactor and anoxic/aerobic-membrane bioreactor. Bioresour. Technol. 2009, 100, 3877-3881. [CrossRef]

21. Ferrentino, R.; Ferraro, A.; Mattei, M.R.; Esposito, G.; Andreottola, G. Process performance optimization and mathematical modelling of aSBR-MBBR treatment at low oxygen concentration. Process Biochem. 2018, 75, 230-239. [CrossRef]

22. Cheng, J.; Liu, B. Nitrification/denitrification in intermittent aeration process for swine wastewater treatment. J. Environ. Eng. 2001, 172, 705-711. [CrossRef]

23. Cosenza, A.; Di Bella, G.; Mannina, G.; Torregrossa, M.; Viviani, G. Biological Nutrient Removal and Fouling Phenomena in a University of Cape Town Membrane Bioreactor Treating High Nitrogen Loads. J. Environ. Eng. 2013, 139, 773-780. [CrossRef]

24. Cosenza, A.; Di Bella, G.; Mannina, G.; Torregrossa, M.; Viviani, G. The role of EPS in fouling and foaming phenomena for a membrane bioreactor. Bioresour Technol. 2013, 147, 184-192. [CrossRef] [PubMed]

25. Mannina, G.; Capodici, M.; Cosenza, A.; Di Trapani, D.; Ekama, G. The effect of the solids and hydraulic retention time on moving bed membrane bioreactor performance. J. Clean. Prod. 2018, 170, 1305-1315. [CrossRef]

26. Liu, G.; Wang, J. Enhanced removal of total nitrogen and total phosphorus by applying intermittent aeration to the Modified Ludzack-Ettinger (MLE) process. J. Clean. Prod. 2017, 166, 163-171. [CrossRef]

27. Mannina, G.; Capodici Cosenza, A.; Di Trapani, D.; Viviani, G. Sequential batch membrane bio-reactor for wastewater treatment: The effect of increased salinity. Bioresour Technol. 2016, 209, 205-212. [CrossRef]

28. Di Trapani, D.; Di Bella, G.B.; Mannina, G.; Torregrossa, M.; Viviani, G. Effect of C/N shock variation on the performances of a moving bed membrane bioreactor. Bioresour Technol. 2015, 189, 250-257. [CrossRef]

(C) 2020 by the authors. Licensee MDPI, Basel, Switzerland. This article is an open access article distributed under the terms and conditions of the Creative Commons Attribution (CC BY) license (http://creativecommons.org/licenses/by/4.0/). 